\title{
A discrete choice experiment to investigate patient preferences for HIV testing programs in Bogotá, Colombia
}

Citation for published version (APA):

Wijnen, B. F. M., Van Engelen, R. P. L. B., Ostermann, J., Muhlbacher, A., Hendriks, A. F. W., Conde, R., Gonzalez, J. G. R., Govers, M. J. G., Evers, S. M. A. A., \& Hiligsmann, M. (2019). A discrete choice experiment to investigate patient preferences for HIV testing programs in Bogotá, Colombia. Expert Review of Pharmacoeconomics \& Outcomes Research, 19(2), 195-201. https://doi.org/10.1080/14737167.2019.1530594

Document status and date:

Published: 01/01/2019

DOI:

10.1080/14737167.2019.1530594

Document Version:

Publisher's PDF, also known as Version of record

\section{Document license:}

Taverne

Please check the document version of this publication:

- A submitted manuscript is the version of the article upon submission and before peer-review. There can be important differences between the submitted version and the official published version of record.

People interested in the research are advised to contact the author for the final version of the publication, or visit the DOI to the publisher's website.

- The final author version and the galley proof are versions of the publication after peer review.

- The final published version features the final layout of the paper including the volume, issue and page numbers.

Link to publication

\footnotetext{
General rights rights.

- You may freely distribute the URL identifying the publication in the public portal. please follow below link for the End User Agreement:

www.umlib.nl/taverne-license

Take down policy

If you believe that this document breaches copyright please contact us at:

repository@maastrichtuniversity.nl

providing details and we will investigate your claim.
}

Copyright and moral rights for the publications made accessible in the public portal are retained by the authors and/or other copyright owners and it is a condition of accessing publications that users recognise and abide by the legal requirements associated with these

- Users may download and print one copy of any publication from the public portal for the purpose of private study or research.

- You may not further distribute the material or use it for any profit-making activity or commercial gain

If the publication is distributed under the terms of Article $25 \mathrm{fa}$ of the Dutch Copyright Act, indicated by the "Taverne" license above, 


\title{
A discrete choice experiment to investigate patient preferences for HIV testing programs in Bogotá, Colombia
} Ben F. M. Wijnen $\mathbb{0}^{\mathrm{a}, \mathrm{b}}$, Ruben P. L. B. Van Engelen*a, Jan Ostermann ${ }^{c}$, Axel Muhlbacher ${ }^{\mathrm{d}, \mathrm{e}}$, Arnolf F. W. Hendriks ${ }^{\mathrm{a}}$,
Rafael Conde ${ }^{\mathrm{f}}$, Javier G. R. Gonzalez $\mathbb{0}^{\mathrm{g}}$, Mark J. G. Govers ${ }^{\mathrm{a}}$, Silvia M. A. A. Evers $\mathbb{1}^{\mathrm{a}, \mathrm{b}}$ and Mickaël Hiligsmann $\mathbb{1}^{\mathrm{a}}$

\begin{abstract}
aDepartment of Health Services Research, CAPHRI (Care and Public Health Research Institute), Maastricht University, Maastricht, The Netherlands;

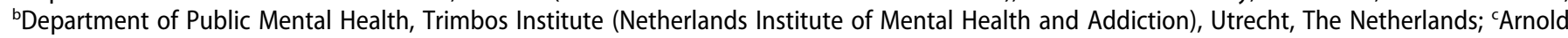
School of Public Health, University of South Carolina, Columbia, South Carolina, United States of America \& Duke Global Health Institute, Duke University, Durham, NC, USA; dCenter for Health Policy and Inequalities Research, Duke University, Durham, NC, USA; ${ }^{\mathrm{e} G e s u n d h e i t s o ̈ k o n o m i e ~ u n d ~}$ Medizinmanagement, Hochschule Neubrandenburg, Neubrandenburg, Germany; ${ }^{\mathrm{f} A s i s t e n c i a ~ C i e n t i ́ f i c a ~ d e ~ A l t a ~ C o m p l e j i d a, ~ C e n t r o ~ d e ~ I n v e s t i g a c i o ́ n ~}$ Clínica ACISC Bogota, Bogata, Colombia; ${ }^{9}$ Rosario Graduate School of Business, School of Business, Administración en Salud, Universidad del Rosario, Bogotá, Colombia
\end{abstract}

\section{ABSTRACT}

Background: To assess patients' preferences for HIV testing in Colombia.

Methods: A discrete choice experiment was used to assess preferences of patients diagnosed with HIV, for HIV testing in two HIV clinics in Bogotá, Colombia. Patients were asked to choose repeatedly between two hypothetical HIV testing options that varied with respect to five attributes: distance to testing site, confidentiality, testing days, sample collection method, and the services if HIV positive. A random parameter model was used to analyze the data.

Results: A total of 249 questionnaires were eligible for data analysis. Respondents showed a preference for testing on weekdays, nobody being aware, a sample taken from the arm, and receiving medications through a referral. The respondents showed a high negative preference for many people being aware, followed by testing during the weekend and home testing. Subgroup analyses by gender and prior testing history did not reveal significant differences.

Conclusion: This study suggests that patients' preferences for HIV testing focused especially on confidentiality, availability during weekdays, and using a sample from the arm. This information could be useful to improve uptake of HIV testing in Bogotá, Colombia.
ARTICLE HISTORY

Received 30 April 2018

Accepted 27 September 2018

\section{KEYWORDS}

Colombia; discrete choice experiment; HIV; patients preferences; testing programs

\section{Introduction}

Globally, the number of human immunodeficiency virus (HIV)infected people is decreasing [1]. In Colombia, however, the number of people infected with HIV is increasing and is estimated to be about 160,000 people, a general population prevalence of $0.5 \%$, but mostly concentrated in high-risk populations (i.e. gay men and female sex workers [2,3]. Between 2012 and 2013, the number of HIV cases increased by $23 \%$ in Bogotá [4]. While progress has been made in diagnosis and treatment in the past decades (e.g. social security), the lack of HIV testing is seen as an important cause for this increasing trend. People are still unaware of their right to be tested in Colombia, and it is has been shown that access to HIV testing in Colombia is still restricted by bureaucratic procedures [5]. In addition, even though policies specify that HIV testing should be free, co-payments are sometimes required for various other appointments such as the risk assessment and counseling. As a result, patients consult late and remain a considerable time as undiagnosed carriers. The national health institute estimated that for every person testing positive for HIV, there could be eight infected persons that are unknown to the national surveillance system. To reduce transmission of the HIV virus, it is essential that people are aware that they are infected, and begin antiretroviral therapy. When people receive antiretroviral therapy, health is preserved both on an individual and population level, and levels of HIV transmission will decrease significantly [6]. Currently in Colombia, the government policy affirms the right to free semi-annual HIV testing [7]. HIV testing is usually done in the hospital or health-care institution attended by the patient and consists of screening tests (e.g. serological ELISA tests or rapid screening tests in circumstances in which the complexity of the laboratory required for ELISA tests is nonexistent) and confirmatory tests (e.g. Western Blot or indirect immune-fluorescence). Testing is often paired with psychological counseling based on the estimated risk of the patient, done in a discreet and highly confidential manner, is aimed to increase the patient's collaboration in the therapeutic process or prevention. Self-testing is currently not available in Colombia. HIV medications are fully reimbursed by either private health insurance under the contributory plan or through a subsidized plan in which the government pays private insurers to provide plans for people who qualify for these subsidized benefits. 
While testing for HIV is the first crucial step in the fight against HIV, testing rates remain very low, including among high-risk groups [8]. In Colombia, only about $20 \%$ of individuals at risk are tested for HIV in their lifetime [9]. Individuals at high risk include men who have sex with men, sex workers, injecting drug users, teenagers, pregnant women, population deprived of liberty and forcibly displaced population, and groups with a low-income level have been shown to be more vulnerable to HIV $[10,11]$. Therefore, there is an urgent need to expand HIV testing, especially among these high-risk populations. Understanding what individuals prefer for HIV testing could provide relevant information for policymakers in order to increase rates of HIV testing that could help to contain HIV distribution. In recent years, there has been an increased attention for preference studies regarding health-care interventions [12]. Preference studies can provide researchers and decision makers with valuable insights how health interventions could be delivered more effectively and more efficiently [13]. Some preference studies about HIV testing have been conducted (e.g. in the United States and Tanzania) [14-16]. In particular, a discrete choice experiment (DCE) was conducted in Tanzania, suggesting that the distance to the testing site was the most important attribute, followed by confidentiality and the manner of collecting a sample to perform an HIV test [16]. Little, however, is known how these results could be transferable to other populations such as Colombia. For example, in Tanzania the high-risk population differs to Colombia in the sense that there is a higher prevalence of HIV among women [17]. To our knowledge, no research has been performed that examines patient preferences for HIV testing programs in Colombia or even South America. Therefore, this study was designed to assess patient preferences for HIV testing in Bogotá, Colombia.

\section{Methods}

\subsection{Discrete choice experiment}

We used a DCE to assess the preferences of HIV patients for HIV testing programs. In the DCE, respondents were asked to make a series of hypothetical choices between two HIV testing alternatives that varied along several attributes. We used a previously designed DCE that was conducted in Tanzania. A brief description of the different components of the DCE is provided below, and further explanation could be found in the previous study [16].

\subsection{Levels and attributes}

We used similar attributes and levels to Ostermann et al. [16]. These attributes and their levels were developed and selected by performing a review on prior literature concerning HIV testing, in-depth interviews, and focus group discussions in Tanzania [16]. Five attributes for HIV testing programs were included: distance to the test site (home, 1, 5, or $20 \mathrm{~km}$ ), the confidentiality of the test (no one knows, the partner knows, many people know about the test), the testing days (weekdays or in the weekend), the way the sample is collected (blood from finger or arm, oral swab), and the services provided if the patient is HIV positive (referral for medication or receive medication at testing site) (see Table 1).
Table 1. Attributes and levels.

\begin{tabular}{|c|c|}
\hline Attribute & Level \\
\hline Distance of testing site & $\begin{array}{l}\text { Home } \\
1 \mathrm{~km} \\
5 \mathrm{~km} \\
20 \mathrm{~km}\end{array}$ \\
\hline Confidentiality HIV test & $\begin{array}{l}\text { Many people are aware that you have been tested } \\
\text { The spouse is aware that you have been tested } \\
\text { No one is aware that you have been tested }\end{array}$ \\
\hline Testing days & $\begin{array}{l}\text { Weekdays } \\
\text { Weekend }\end{array}$ \\
\hline Type of sample taken & $\begin{array}{l}\text { Arm } \\
\text { Finger } \\
\text { Mouth }\end{array}$ \\
\hline Services if HIV positive & $\begin{array}{l}\text { Referral to a HIV treatment centre for medication } \\
\text { Obtain medication at testing site }\end{array}$ \\
\hline
\end{tabular}

HIV: human immunodeficiency virus.

\subsection{Experimental design}

The experimental design was similar to the study conducted in Tanzania (14). A D-efficient statistical design using Ngene (versions 1.1.1) software (ChoiceMetrics, Sydney, Australia) was used to select the choice sets. In total, each questionnaire contained nine choice sets and eight different versions were designed to improve efficiency. An example of a choice set is shown in Figure 1. The questionnaire was initially designed in English and translated in Spanish by a clinician (a native speaker). The final questionnaire consisted of an introduction of the study, a description of the five attributes and the different levels of the attributes, and an example question, with an explanation to assist the respondent in understanding the choice set. In addition, respondents were asked to indicate any further attributes that could be important to them.

\subsection{Data collection and participants}

A pilot study was first performed with five respondents from the target group to assess whether the respondents had any difficulties with the questionnaire. Only minor changes were done in the wording to increase understandability. The data collection was performed in May 2016 with HIV patients receiving treatment at two separate locations: 'Infectologos Clinicos De Colombia SAS Infectoclinicos' and 'Asistencia Cientifica de Alta Complejidad (ACAC)' both are located in Bogotá, Colombia. These sites were chosen as it would be a convenient way to approach a reasonable number of respondent's familiar with HIV testing. Patients were recruited by approaching them in the waiting rooms of both clinics. The questionnaire was self-administrated. The people handing out the questionnaires provided support to the participants who were having difficulties with the questionnaires. Before the respondents were allowed to start with the questionnaire, the respondents must have given informed consent that he/ she was willing to participate in the study. The study received ethics approval from the ACAC.

\subsection{Data analysis}

We only included questionnaires where at least seven choice sets were completed. A mixed logit model (also 


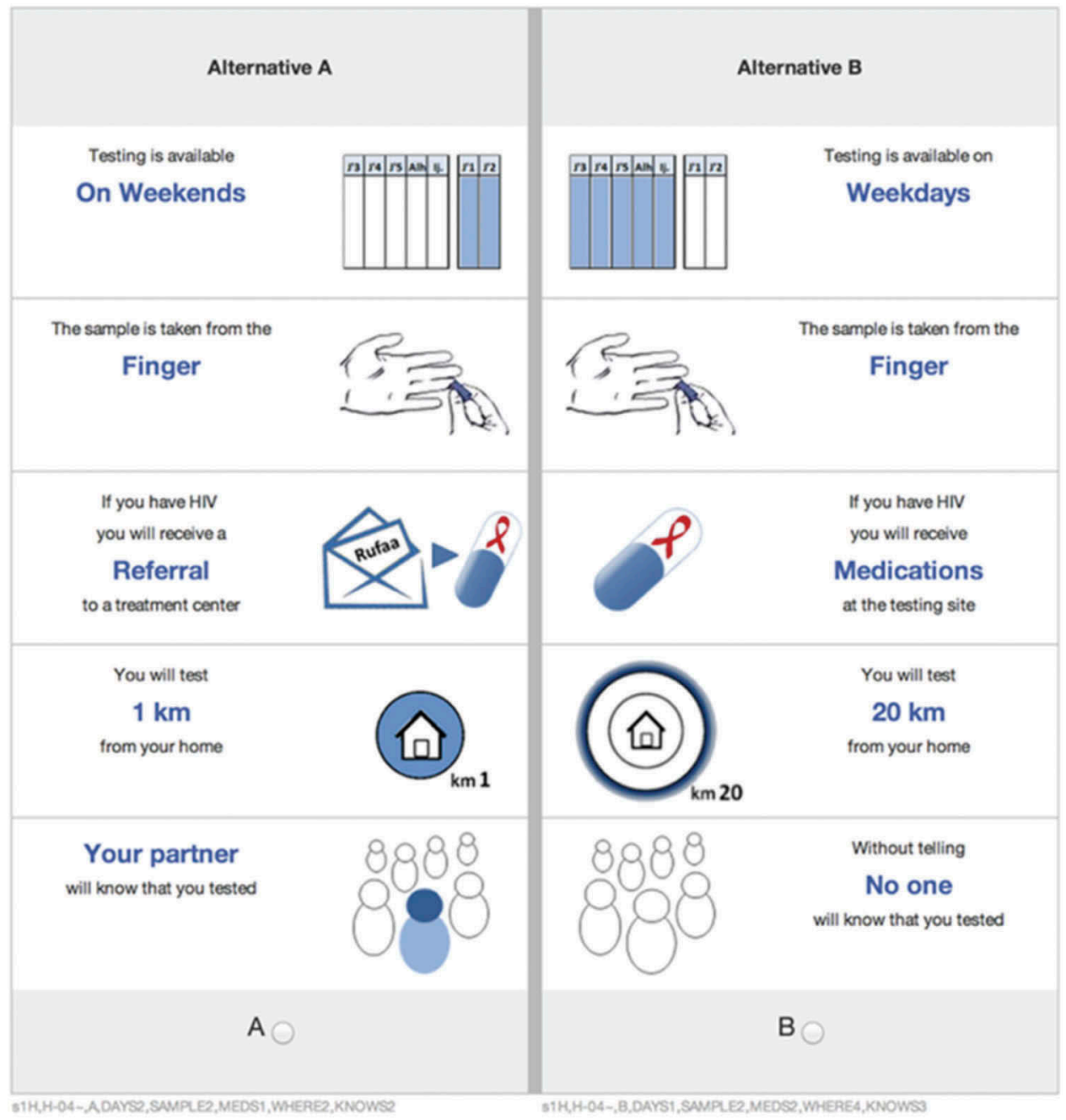

Which of these two alternatives would you choose, alternative $A$ or alternative $B$ ?

Figure 1. An example of a choice task from the questionnaire, adapted from Ostermann et al. [16].

called random parameter model) was used to analyze the data. This model is based on the assumption that parameters are randomly distributed in the population and captures heterogeneity by estimating the standard deviation of the parameter's distribution. We used a panel mixed logit model to account for the panel nature of the data as each patient completed nine choice sets. Effects coding was used to describe the categorical variables. Using effect coding, mean attributes are normalized to zero and preference weights are relative to the mean effect of the different levels of the attribute. A positive sign for a given level therefore indicates a level has a positive effect on utility compared to the mean effect of the attribute. All random parameters were drawn from a normal distribution. If the standard deviation of the random parameters is significantly different from zero, this is interpreted as evidence of significant preference heterogeneity for the attribute within the population. The estimation was conducted by using 2000 Halton draws. Two subgroup analyses were performed to assess the impact of gender and of a recent HIV diagnosis (in the last year) on preferences. A joint model using dummy variables was estimated using interaction terms to capture potentially systematic differences in preference between subgroups. To take scale heterogeneity into account and thus to control for the fact that differences between countries can also be due to difference in the unobserved error scale, a normally distributed random component was added for each country dummy. This allowed us to test whether a significant difference in the interaction terms reflected a systematic difference in preference, and not merely a difference in the scale of the random error between countries [18].

\section{Results}

\subsection{Patient characteristics}

The characteristics of the patients are depicted in Table 2. A total of 283 questionnaires were returned; however, only 249 of those questionnaires were eligible for inclusion, with one questionnaire not eligible due to the absence of an informed consent and 33 not meeting the criteria of 
Table 2. Patients' characteristics.

\begin{tabular}{|c|c|c|c|}
\hline & Total & Men & Women \\
\hline Number of participants & $\begin{array}{c}249 \\
\text { Mean (SD) or percent }\end{array}$ & $\begin{array}{c}187 \\
\text { Mean (SD) or percent }\end{array}$ & $\begin{array}{c}43 \\
\text { Mean (SD) or percent }\end{array}$ \\
\hline \multicolumn{4}{|l|}{ Social demographic characteristics } \\
\hline Age (years) & $38(11.5)$ & $38(13.0)$ & $37(14.5)$ \\
\hline \multicolumn{4}{|l|}{ Marital status } \\
\hline Single & $44 \%$ & $51 \%$ & $33 \%$ \\
\hline Married or living together & $31 \%$ & $33 \%$ & $37 \%$ \\
\hline Widowed & $3 \%$ & $2 \%$ & $7 \%$ \\
\hline Divorced & $5 \%$ & $5 \%$ & $7 \%$ \\
\hline Other & $9 \%$ & $9 \%$ & $14 \%$ \\
\hline \multicolumn{4}{|l|}{ Level of education } \\
\hline Elementary uncompleted & $5 \%$ & $4 \%$ & $12 \%$ \\
\hline Elementary complete & $6 \%$ & $5 \%$ & $16 \%$ \\
\hline Secondary complete & $37 \%$ & $36 \%$ & $56 \%$ \\
\hline Higher education complete & $43 \%$ & $54 \%$ & $16 \%$ \\
\hline \multicolumn{4}{|l|}{ Employment status } \\
\hline Student & $8 \%$ & $8 \%$ & $9 \%$ \\
\hline Unemployed & $8 \%$ & $7 \%$ & $9 \%$ \\
\hline Self-employed & $32 \%$ & $40 \%$ & $12 \%$ \\
\hline Casual laborer & $5 \%$ & $6 \%$ & $5 \%$ \\
\hline Employed & $31 \%$ & $35 \%$ & $25 \%$ \\
\hline Houseman/wife & $7 \%$ & $1 \%$ & $37 \%$ \\
\hline \multicolumn{4}{|l|}{ Number of children } \\
\hline 0 & $60 \%$ & $75 \%$ & $21 \%$ \\
\hline 1 & $12 \%$ & $9 \%$ & $32 \%$ \\
\hline 2 & $8 \%$ & $4 \%$ & $30 \%$ \\
\hline 3 & $6 \%$ & $6 \%$ & $7 \%$ \\
\hline 4 or more & $5 \%$ & $4 \%$ & $9 \%$ \\
\hline \multicolumn{4}{|l|}{ HIV-related questions } \\
\hline \multicolumn{4}{|l|}{ Route of infection } \\
\hline Heterosexual & $26 \%$ & $21 \%$ & $60 \%$ \\
\hline Homosexual & $48 \%$ & $62 \%$ & $5 \%$ \\
\hline Drug injection & $2 \%$ & $3 \%$ & $0 \%$ \\
\hline Hospitalization & $5 \%$ & $4 \%$ & $12 \%$ \\
\hline From mother to child & $2 \%$ & $2 \%$ & $2 \%$ \\
\hline Other & $7 \%$ & $5 \%$ & $16 \%$ \\
\hline \multicolumn{4}{|l|}{ Number of sexual partners (lifetime) } \\
\hline 0 & $3 \%$ & $3 \%$ & $2 \%$ \\
\hline 1 & $11 \%$ & $8 \%$ & $28 \%$ \\
\hline 2 to 5 & $26 \%$ & $24 \%$ & $44 \%$ \\
\hline 6 or more & $52 \%$ & $63 \%$ & $23 \%$ \\
\hline Received money or gifts for sex & $18 \%$ & $21 \%$ & $9 \%$ \\
\hline \multicolumn{4}{|l|}{ Alcohol consumption } \\
\hline Never & $15 \%$ & $14 \%$ & $28 \%$ \\
\hline Few times a year & $48 \%$ & $52 \%$ & $51 \%$ \\
\hline Few times a month & $23 \%$ & $27 \%$ & $14 \%$ \\
\hline Few times a week/daily & $5 \%$ & $6 \%$ & $0 \%$ \\
\hline Traveled and slept away from home in past year & $68 \%$ & $79 \%$ & $44 \%$ \\
\hline Had other STD's (yes/no; self-reported) & $20 \%$ & $26 \%$ & $5 \%$ \\
\hline \multicolumn{4}{|l|}{ Domestic violence } \\
\hline Physical & $1 \%$ & $2 \%$ & $0 \%$ \\
\hline Psychological & $6 \%$ & $6 \%$ & $5 \%$ \\
\hline \multicolumn{4}{|l|}{ Stage of HIV/AIDS } \\
\hline Only HIV infection & $44 \%$ & $48 \%$ & $44 \%$ \\
\hline Stage 1 & $18 \%$ & $19 \%$ & $21 \%$ \\
\hline Stage 2 & $11 \%$ & $12 \%$ & $9 \%$ \\
\hline Stage 3 & $6 \%$ & $7 \%$ & $5 \%$ \\
\hline Stage 4 & $3 \%$ & $3 \%$ & $7 \%$ \\
\hline Number of years under HIV/AIDS treatment & $7.6(6.6)$ & 7.4(6.4) & $8.7(7.55)$ \\
\hline Number of times of diagnostic test before being diagnosed & $2.4(2.14)$ & $2.5(2.23)$ & $2.0(1.66)$ \\
\hline Diagnostic test the past year & $45 \%$ & $50 \%$ & $42 \%$ \\
\hline
\end{tabular}

HIV: human immunodeficiency virus; SD: standard deviation; STD: Sexually transmitted diseases.

at least seven DCE choice sets answered. The majority of the participants were men $(75 \%)$, and the mean age was 38 years. Nearly two-thirds of the male participants contracted HIV through homosexual relations. Sixty percent of women contracted HIV through heterosexual contact. Our population is very similar to the overall HIV/AIDS population in Colombia with most cases being aged between 35 and 39 years, and $72.83 \%$ of cases in the male population [19].

\subsection{Patients' preferences}

The results of the panel mixed logit model are shown in Table 3. A total of 2212 choices were made by the participants (249 
Table 3. Results of the panel mixed logit model.

\begin{tabular}{llcl}
\hline Attribute & \multicolumn{1}{c}{ Level } & Estimates (SD) & Std Dev $^{\mathrm{a}}$ \\
\hline Distance & Home & -0.33 & \\
& $1 \mathrm{~km}$ & $0.04(0.08)$ & $0.26^{* *}$ \\
& $5 \mathrm{~km}$ & $0.24(0.07)^{* * *}$ & $0.31^{* *}$ \\
Confidentiality & $20 \mathrm{~km}$ & $0.05(0.10)$ & 0.24 \\
& Many people & $-0.56(0.07)^{* * *}$ & $0.70^{* * *}$ \\
& Spouse & $0.06(0.06)$ & $0.65^{* * *}$ \\
Testing days & No one & 0.50 & \\
& Weekdays & $0.38(0.08)^{* * *}$ & $0.65^{* * *}$ \\
Type of sample & Weekends & $-0.38^{* * *}$ & \\
& Arm & 0.27 & \\
Services if HIV positive & Finger & $-0.01(0.05)$ & $0.25^{* * *}$ \\
& Routh & $-0.26(0.06)^{* * *}$ & $0.30^{* * *}$ \\
Log likelihood & Medications & $0.08(0.03)^{* *}$ & 0.09 \\
Number of observations & & $-0.08^{* *}$ & \\
Pseudo R-squared & & -1343.14 & \\
& & 2212 & \\
\hline
\end{tabular}

${ }^{*} p<0.10,{ }^{* *} p<0.05,{ }^{* * *} p<0.01$

a Std Dev values correspond to the random component of the model coefficients (as opposed to the standard deviations of the coefficients themselves reported as SDs).

respondents $\times 9$ choice sets -29 missing values). The confidentiality was the most important attribute for an HIV test, with a high negative preference for many people being aware that a person has been tested. The respondents also showed a preference for the test being available on weekdays over weekends, a negative preference for a test being available at home, a positive preference for a sample taken from the arm with a negative preference for a sample taken from the mouth, and a slight preference for receiving HIV medication through a referral at a treatment center over receiving medications at the testing site. We also observed that a testing site $5 \mathrm{~km}$ away from home was preferred over testing at home. Standard deviations parameters were significant for most of the attributes/levels, indicating the presence of preference heterogeneity between patients and hence variations in the importance of the attributes/levels.

\subsection{Subgroup analyses}

In Tables 4 and 5, the results of the subgroup analyses are displayed. Table 4 shows the results of the subgroup analysis of preferences of HIV patients for gender. No significant difference ( $5 \%$ level) in preferences was observed between male and female. In Table 5, the results of the subgroup analysis on the preferences of HIV are displayed, divided by whether or not they were tested for HIV in the past year. No significant difference between subgroups was observed.

\section{Discussion}

This study suggests that all attributes (i.e. distance to the test site, the confidentiality of the test, the testing days, the way the sample is collected, the services provided if the patient is HIV positive) are significant and therefore important for HIV testing programs. Respondents showed a preference for testing days being on weekdays, a testing site at a distance of $5 \mathrm{~km}$ away from home, for nobody being aware that they have been tested, a sample taken from the arm, and for receiving medications through a referral for a medical center. The respondents showed the highest negative preference for many people being aware that they have tested for HIV followed by the testing days during the weekend and testing for HIV from home; the respondents also showed a negative preference for a sample taken from the mouth and a slight negative preference for receiving medications at the testing site. The subgroup analyses did not yield significant differences. The respondents' preference for a testing site being 5 $\mathrm{km}$ away from home was not expected, it could, however, indicate that the respondents prefer the testing site to be farther away from home but not too far away. Moreover, given that Bogotá is a fairly large city (i.e. with approximately 8 million inhabitants), it could be that patients perceive $5 \mathrm{~km}$ as sufficiently anonymous. From some discussions with patients outside of the experiment (i.e. not protocol driven), it appeared that they did not believe testing from home could

Table 4. Subgroup analysis of preferences of HIV patient for diagnostic according to gender.

\begin{tabular}{|c|c|c|c|c|c|c|}
\hline \multirow[b]{2}{*}{ Attribute } & \multirow[b]{2}{*}{ Level } & \multicolumn{2}{|c|}{ Men $(n=147)$} & \multicolumn{2}{|c|}{ Women $(n=43)$} & \multirow[b]{2}{*}{$p$-Value ${ }^{\mathrm{b}}$} \\
\hline & & Estimates (SD) & $\operatorname{Std~Dev}^{a}$ & Estimates (SD) & Std Dev & \\
\hline \multirow[t]{3}{*}{ Distance } & Home & -0.35 & & -0.15 & & \\
\hline & $1 \mathrm{~km}$ & $0.10(0.11)$ & $0.42^{* * *}$ & $0.09(0.18)$ & 0.09 & 0.90 \\
\hline & $20 \mathrm{~km}$ & $-0.02(0.13)$ & 0.20 & $0.08(0.22)$ & 0.01 & 0.88 \\
\hline \multirow[t]{3}{*}{ Confidentiality } & Many people & $-0.68(0.10)^{* * *}$ & $0.85^{* * *}$ & $-0.31(0.15)^{* * *}$ & $0.59^{* * *}$ & 0.12 \\
\hline & Spouse & $0.09(0.09)$ & $0.78^{* * *}$ & $-0.03(0.11)$ & 0.29 & 0.37 \\
\hline & No one & 0.60 & & 0.34 & & \\
\hline \multirow[t]{3}{*}{ Type of sample } & Arm & 0.28 & & 0.35 & & \\
\hline & Finger & $-0.06(0.07)$ & $0.30^{* *}$ & $0.08(0.11)$ & 0.01 & 0.25 \\
\hline & Mouth & $-0.22(0.07)^{* * *}$ & $0.38^{* * *}$ & $-0.44(0.14)^{* * *}$ & $0.38^{*}$ & $0.08^{*}$ \\
\hline \multirow[t]{2}{*}{ Services if HIV positive } & Referral & $0.08(0.04)^{* * *}$ & 0.10 & $0.12(0.08)$ & $0.28^{* *}$ & 0.57 \\
\hline & Medications & $-0.08^{* * *}$ & & -0.12 & & \\
\hline Log likelihood & & -983.42 & & -239.90 & & \\
\hline
\end{tabular}

${ }^{*} p<0.10,{ }^{* *} p<0.05,{ }^{* * *} p<0.01$

aStd Dev values correspond to the random component of the model coefficients (as opposed to the standard deviations of the coefficients themselves reported as SDs)

${ }^{\mathrm{b}} p$-Value of the interaction coefficient to assess whether the attribute/level differs between both groups. 
Table 5. Subgroup analysis of preferences of HIV patients for diagnostic according to being tested for HIV the last year.

\begin{tabular}{|c|c|c|c|c|c|c|}
\hline \multirow[b]{2}{*}{ Attribute } & \multirow[b]{2}{*}{ Level } & \multicolumn{2}{|c|}{ Tested last year $(n=112)$} & \multicolumn{2}{|c|}{ Not tested last year $(n=106)$} & \multirow[b]{2}{*}{$p$-Value ${ }^{\mathrm{b}}$} \\
\hline & & Estimates (SD) & Std Dev ${ }^{a}$ & Estimates (SD) & Std Dev & \\
\hline \multirow[t]{4}{*}{ Distance } & Home & -0.39 & & -0.06 & & \\
\hline & $1 \mathrm{~km}$ & $0.08(0.10)$ & $0.32 * *$ & $0.26(0.23)$ & 0.03 & 0.60 \\
\hline & $5 \mathrm{~km}$ & $0.28(0.08)^{* * *}$ & $0.33^{* * *}$ & $0.04(0.20)$ & 0.49 & 0.19 \\
\hline & $20 \mathrm{~km}$ & $0.02(0.12)$ & 0.26 & $-0.25(0.29)$ & 0.61 & 0.49 \\
\hline \multirow[t]{3}{*}{ Confidentiality } & Many people & $-0.54(0.09)^{* * *}$ & $0.71^{* * *}$ & $-0.900 .23)^{* * *}$ & $0.59 * * *$ & 0.20 \\
\hline & Spouse & $0.01(0.08)$ & $0.71^{* * *}$ & $0.29(0.17)^{*}$ & 0.29 & 0.24 \\
\hline & No one & 0.53 & & 0.61 & & \\
\hline \multirow[t]{2}{*}{ Testing days } & Weekdays & $0.38(0.09)^{* * *}$ & $0.67^{* * *}$ & $0.31(020)$ & $0.69^{* * *}$ & 0.59 \\
\hline & Weekends & $-0.38^{* * *}$ & & -0.31 & & \\
\hline \multirow[t]{3}{*}{ Type of sample } & Arm & 0.28 & & 0.54 & & \\
\hline & Finger & $0.04(0.06)$ & 0.09 & $-0.21(0.13)$ & 0.17 & $0.09 *$ \\
\hline & Mouth & $-0.24(0.07)^{* * *}$ & $0.39 * * *$ & $-0.34(0.16)^{* *}$ & $0.48^{* *}$ & 0.77 \\
\hline \multirow[t]{2}{*}{ Services if HIV positive } & Referral & $0.07(0.04)$ & 0.10 & $0.16(0.09)^{*}$ & 0.02 & 0.42 \\
\hline & Medications & -0.07 & & $-0.16^{*}$ & & \\
\hline Log likelihood & & -983.03 & & -221.31 & & \\
\hline
\end{tabular}

${ }^{*} p<0.10,{ }^{* *} p<0.05,{ }^{* * *} p<0.01$

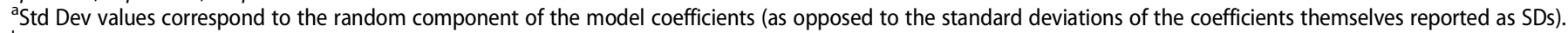

${ }^{\mathrm{b}} p$-Value of the interaction coefficient to assess whether the attribute/level differs between both groups.

be possible, because this option is not offered in the Colombian health system. This could potentially explain the negative preference for being tested at home. This could indicate that for some participants feasibility of the attributes was also taken into account.

The outcomes of this study differ to some extent from the study of Ostermann et al. [16] that used a similar DCE in Tanzania. In Ostermann et al. [16], the most important attribute was the distance of the testing site, followed by confidentiality and the method for taking a sample to test for HIV. In our study, confidentiality was the most important attribute, followed by testing days and distance of the testing site. In addition, the study of Ostermann et al. [16] also showed some significant differences between males and females and those who tested in the past year and those who tested more than a year ago. We did not find any significant differences between men and women.

The findings from this study could be important for policymakers for improving the use and effectiveness of HIV testing programs in Bogotá, Colombia and to aid in the battle against HIV/AIDS, especially given the high number of HIV patients in Colombia and the fact that a high number of people are unaware of the fact that they are infected. In particular, programs should guarantee the confidentiality, being available during weekdays and preferably using a sample from the arm.

Our finding suggests that confidentiality is a barrier for the Colombian population, due to the stigma that the disease continues to carry with it. Another important attribute that could influence the uptake of HIV testing is the testing days, by only testing during weekdays, or by allowing for more flexibility in the planning of the HIV test according to the wishes of the patient; the uptake could also be increased due to the high negative preference for testing during the weekend. The negative preference for taking an oral sample can also be a barrier to get tested for HIV. The population should be better informed about the efficacy of the different ways to test for HIV.

This study has some potential limitations. First, the participants were all diagnosed with HIV. It would be interesting to further investigate the preferences of non-diagnosed patients with HIV to assess if their preferences could differ. Second, the generalizability of our results could be limited. Our study was only collected in two centers in Bogotá and not in other places in Colombia, which could cause the results not to be representative of the entire population of Colombia. Further research would then be needed to study preferences in other sites in Colombia for a better representation of the entire Colombian population, and including participants who have not been diagnosed with HIV. Third, there was a barrier for illiterate patients to participate in the study, because the questionnaire contained a lot of written text, this seemed to scare off potential participants and could lead to selection bias. Fourth, we used a previously developed DCE, no research was performed to formulate an original attribute list with levels, which could lead to additional attributes of an HIV testing program that are potentially important to the Colombian HIV patients, being left out of the study.

\section{Conclusion}

To our knowledge, this is of the first study to assess preferences for HIV testing in South America. Our study suggests that patients from Bogotá, Colombia, have preferences for attributes of HIV testing, in particular for confidentiality, testing days, and distance to testing site. Adjusting HIV testing programs according to the preferences of the patient population could result in testing programs that can be delivered more efficiently and effectively to the population.

\section{Key issues}

- This study suggests that patients from Bogota, Colombia, have preferences for attributes of HIV testing, in particular for confidentiality, testing days, and distance to testing site.

- Adjusting HIV testing programs according to the preferences of the patient population could result in testing 
programs that can be delivered more efficiently and effectively to the population.

\section{Author contributions}

All author(s) made substantial contributions to the paper. BFMW, RPLBE, and $\mathrm{MH}$ were involved in drafting the manuscript, analysis, and interpretation of the data. JO and AM were involved in the design of the questionnaire and interpretation of the data. AFWH, RC, JGRG, and MJGG were involved in interpretation of the data and the collection of data. SMAAE and $\mathrm{MH}$ both supervised the project. In addition, all authors were involved in proofreading the manuscript.

\section{Funding}

This paper was not funded.

\section{Declaration of interest}

The authors have no relevant affiliations or financial involvement with any organization or entity with a financial interest in or financial conflict with the subject matter or materials discussed in the manuscript. This includes employment, consultancies, honoraria, stock ownership or options, expert testimony, grants or patents received or pending, or royalties.

\section{Reviewer disclosures}

Peer reviewers on this manuscript have no relevant financial or other relationships to disclose.

\section{ORCID}

Ben F. M. Wijnen (D) http://orcid.org/0000-0001-7993-1905

Javier G. R. Gonzalez (10) http://orcid.org/0000-0001-6693-3901

Silvia M. A. A. Evers (D) http://orcid.org/0000-0003-1026-570X

Mickaël Hiligsmann (D) http://orcid.org/0000-0003-4274-9258

\section{References}

Papers of special note have been highlighted as either of interest ( $\cdot)$ or of considerable interest (.•) to readers.

1. UNAIDS. UNAIDS report on the global AIDS epidemic. Geneva: UNAIDS; 2012.

2. Arrivillaga M, Hoyos $P$, Tovar $L$, et al. HIV testing and counselling in Colombia: evidence from a national health survey and recommendations for health-care services. Int J STD AIDS. 2012;23(11):815-821.

-. Impotant reference which highlights barriers of HIV testing in Colombia and sheds light on high-rik populations

3. Wells M HIV/AIDS falls wordwide, rises in Colombia: Colombia reports; 2011 [cited 201601 16]. Available from: http://colombiare ports.com/hivaids-falls-worldwide-rises-in-colombia/
4. McKenzie V HIV cases have increased by $23 \%$ in Bogota: health secretary: colombia reports; 2014 [cited 201610 01]. Available from: http:// colombiareports.com/hiv-cases-increased-23-bogota-ministry-health/

5. Reisen CA, Zea MC, Bianchi FT, et al. HIV testing among MSM in Bogotá, Colombia: the role of structural and individual characteristics. AIDS Educ Prev. 2014;26(4):328-344.

6. Cohen MS, Chen YQ, McCauley M, et al. Prevention of HIV-1 infection with early antiretroviral therapy. N Engl J Med. 2011;365 (6):493-505.

7. Ministro de la Protección Social de la República de Colombia. CIRCULAR No. 0063. Bogota, 2006.

8. Ostermann J, Njau B, Mtuy T, et al. One size does not fit all: HIV testing preferences differ among high-risk groups in Northern Tanzania. AIDS Care. 2015;27(5):595-603.

9. Galindo-Quintero J, Mueses-Marin HF, Montaño-Agudelo D, et al. HIV testing and counselling in colombia: local experience on two different recruitment strategies to better reach low socioeconomic status communities. AIDS Res Treat. 2014;2014.

10. Montano SM, Sanchez JL, Laguna-Torres A, et al. Prevalences, genotypes, and risk factors for HIV transmission in South America. JAIDS J Acquired Immune Deficiency Syndromes. 2005;40(1):57-64.

11. Mueses HF, Pinzón MV, Tello IC, et al. HIV and risk behaviors of persons of low socio-economic status, Popayan-Colombia (20082009). Colombia Médica. 2013;44(1):7-12.

12. Ryan $M$, Scott $D$, Reeves $C$, et al. Eliciting public preferences for healthcare: a systematic review of techniques. 2001.

- Influencial review that provides an overview of preference elicitation in health care.

13. Neumann PJ, Goldie SJ, Weinstein MC. Preference-based measures in economic evaluation in health care. Annu Rev Public Health. 2000;21(1):587-611.

14. Hutchinson AB, Corbie-Smith $G$, Thomas SB. Understanding the patient's perspective on rapid and routine HIV testing in an inner-city urgent care center. AIDS Educ Prevent. 2004;16(2):101114.

15. Phillips KA, Maddala T, Johnson FR. Measuring preferences for health care interventions using conjoint analysis: an application to HIV testing. Health Serv Res. 2002;37(6):1681-1705.

16. Ostermann J, Njau B, Brown DS, et al. Heterogeneous HIV testing preferences in an urban setting in Tanzania: results from a discrete choice experiment. PLoS One. 2014;9(3):e92100.

.- Important DCE on which the current DCE was based.

17. Rwegerera GM, Moshomo T, Gaenamong M, et al. Antidiabetic medication adherence and associated factors among patients in Botswana; implications for the future. Alexandria J Med. 2018 2018/ 06/01/;54(2):103-109.

18. Hiligsmann M, Dellaert BG, Dirksen CD, et al. Patients' preferences for anti-osteoporosis drug treatment: a cross-European discrete choice experiment. Rheumatology (Oxford). 2017 Jul 01;56 (7):1167-1176. PubMed PMID: 28398547; PubMed Central PMCID: PMCPMC5563450.

19. Cohen CJ, Flaks-Manov N, Low M, et al. High-risk case identification for use in comprehensive complex care management. Popul Health Manag. 2015;18(1):15-22. 